\title{
Trans-Parliamentary Associations in Global Functional Agencies
}

\author{
by Steve Charnovitz
}

\section{Introduction}

Although elected parliamentarians have well-studied official roles in national legislative bodies (and in the European Union), the transnational activities of parliamentarians has received less scholarly attention. Until recently, the main outlet for such parliamentary activity was the Inter-Parliamentary Union (IPU), which undertakes transnational action on the full range of issues. ${ }^{1}$ Other notable trans-parliamentary efforts have included issuespecific parliamentary groups, such as Parliamentarians for Global Action and the Global Legislators for a Balanced Environment (GLOBE). ${ }^{2}$ These groups attend intergovernmental conferences in the same way that nongovernmental organizations (NGOs) and private economic actors do.

Over the past decade, however, a new development has occurred. Catalyzed by the IPU and sometimes aided by the European Parliament, parliamentarians from around the world have come together to focus on a particular international organization. Although such parliamentary confabulations are not directly connected to the international organization, they have a political significance beyond typical nongovernmental activism.

The systematic involvement of parliamentarians at intergovernmental organizations has an important potential for helping to improve global governance. Because the national parliamentarians are elected officials, they have personal legitimacy in carrying out oversight functions over an international agency. Even though their role is informal, a broad group of parliamentarians will be taken seriously by national diplomats and international civil servants because of the authoritative role that parliamentarians play in their home countries.

Is it possible that such trans-parliamentary associations could serve as an antidote to the syndrome of democratic deficit in international governmental organizations? Probably not if such activity remains informal and episodic. Yet if parliamentarians show that they have staying power and develop expertise on specific international organizations, then the governments in the organization may decide to formalize the role of the parliamentarians as an advisory or oversight body. This will require national parliaments to select representatives specifically for the double function (dédoublement fonctionnel').

The earliest example that has come to my attention of agency-specific parliamentary action is the Parliamentary Assembly of the North Atlantic Treaty Organization (NATO). ${ }^{3}$ The Assembly originated in 1955 as the North Atlantic Assembly and continues to carry out activities on a regular basis. Although it is completely independent of NATO, the Assembly aligns its work closely with that of NATO. For example, in October 2001, the Assembly passed a Declaration on the Fight Against Terrorism. 
Delegates to the NATO Parliamentary Assembly are nominated by their parliaments according to national procedures, on the basis of party representation in parliament.

One of the newest functional efforts is the Parliamentary Network on the World Bank. Parliamentary conferences focusing on the World Bank began in May 2000. The most recent - the Second Parliamentary Conference on the World Bank was held in January 2001 in London, at the invitation of a select committee of the House of Commons. In 2002, the Network plans to hold events at the International Conference on Financing for Development and at the World Summit on Sustainable Development. Although the World Bank cooperates with these efforts, the Network has no official connection to the Bank.

It was the IPU that recognized the need for more functional parliamentary action. Beginning at the International Conference on Population and Development in Cairo in 1994, the IPU began hosting a "Parliamentarian's Day" at some of the U.N. global conferences. ${ }^{4}$ Such sessions were also held at: the World Summit for Social Development in Copenhagen in 1995; the Fourth World Conference on Women in Beijing in 1995; and at the World Food Summit in Rome in 1996. In 1998, the IPU held a parliamentary round table at the Second Session of the Conference of the Parties to the U.N. Convention to Combat Desertification, held in Dakar. In February 2000, the IPU held a parliamentary meeting at most recent session of the U.N. Conference on Trade and Development (UNCTAD X) held in Bangkok. The IPU also sponsored (along with the European Parliament) a Parliamentary Meeting held at the November 2001 at the World Trade Organization (WTO) Ministerial Conference in Doha, Qatar. This new parliamentary interest in the world trading system will be discussed below.

\section{Parliamentary Input into the WTO}

The inspiration for the idea of a parliamentary meeting alongside the WTO came from the late U.S. Senator Bill Roth, who was chairman of the U.S. Senate Finance Committee and active in inter-parliamentary affairs. Roth led the efforts to organize a meeting of parliamentarians at the WTO Ministerial Conference in Seattle in November 1999. The purpose of that meeting, said Roth, was for elected officials to "play a more significant role" in the WTO and to learn more about it. At the conference, Roth suggested that a parliamentary forum could "reinforce the legitimacy" of the WTO and engender greater openness and transparency. ${ }^{5}$ In Seattle, WTO Director-General Mike Moore addressed the parallel parliamentary gathering which he called "important" and suggested that it become a "permanent part of the process." 6

As the WTO worked to recover from the debacle in Seattle, Moore spoke favorably about parliamentary attention to the WTO on several occasions. For example, in a speech to a European Parliament committee in February 2000, Moore declared that "Elected representatives are the main expression of civil society," and "Elected representatives have a responsibility to become more involved, hold hearings, scrutinise where the taxpayer's money is going and ensure that the great international institutions created to 
manage global affairs have the moral authority that comes from the ownership and participation of Member governments.",

In July 2000, at the 69th (biennial) conference of the International Law Association, the Committee on International Trade Law approved a Declaration on the Rule of Law in International Trade. ${ }^{8}$ The Declaration called for enhancing the transparency and legitimacy of WTO law and specifically recommended the creation of a WTO advisory economic and social committee or an advisory parliamentary body to be consulted regularly by WTO organs.

In June 2001, the IPU organized a parliamentary meeting on international trade held in Geneva. The meeting included 182 members of parliament from 71 national parliaments. ${ }^{9}$ WTO Director-General Moore addressed the meeting and complimented the sponsor by calling the IPU "politicians without borders." that "Parliamentarians have a vital role to play in bringing international organizations and people closer together and holding us and governments accountable." He closed his speech with: "Can I suggest that we should assemble more often and that all the multilateral institutions that you have created, that you own, could do with your assistance and scrutiny."

At the Parliamentary Meeting, the delegates adopted a Final Declaration which contained both substantive and procedural recommendations. ${ }^{11}$ Among the substantive recommendations was a statement of the "need to ensure that trade rules and practices do not undermine sustainable development goals." Procedurally, the meeting agreed that at the international level, parliamentarians need to complement national activities "by meeting to obtain and share information, exchange views and experiences, and discuss the structure, working methods and issues facing governments at the WTO."

At Doha, there was a parliamentary meeting hosted by the IPU jointly with the European Parliament. ${ }^{12}$ About 100 parliamentarians attended, the number having been reduced by the difficulty of getting to Doha. The meeting adopted a Final Declaration which stated that "parliamentary participation is necessary to ensure a better representation of citizens" and called for a "parliamentary dimension to the WTO." ${ }^{3}$ The parliamentarians asked the governments to include in the Doha Ministerial Declaration a statement in favor of "associating Parliaments more closely with the activities of the WTO." Nevertheless, the government ministers did not do so.

The parliamentary meeting agreed to set up a steering committee to present options for pursuing the next steps. The Declaration notes that there is a disagreement between those who want to establish a standing body of parliamentarians for the WTO and those who want to work through the IPU. The European Parliament group favors a standing parliamentary body for the WTO which would seek a consultative status. ${ }^{14}$ The alternative, more minimalist conception, championed by the IPU and WTO officials, would have the IPU sponsor occasional meetings. ${ }^{15}$ Analyzing this controversy, Fergus Watt, the executive director of the World Federalists of Canada, suggested that NGOs 
advocate the well-structured parliamentary assembly approach over the IPU's weaker parliamentary forum approach. ${ }^{16}$

A few weeks after the Doha Conference, European Commission for Trade Pascal Lamy discussed parliamentary involvement in the WTO in the speech to the Conference on the Participation and Interface of Parliamentarians and Civil Societies for Global Policy. ${ }^{17}$ Lamy stated that he saw merit in discussing the establishment of a WTO Parliamentary Consultative Assembly, which could "lead to stronger public support for the multilateral trading system, by making sure that societal choices and collective preferences are fed into the WTO process." Lamy also reported that there was resistance by some developing country governments to stronger involvement of parliaments in the WTO.

Increasing parliamentary involvement in the WTO could bring several benefits. The most important is that it could solidify the democratic legitimacy of the trading system. As an international organization with delegated authorities, the WTO has an attenuated relationship with the global and national publics. One way to overcome this lengthy "legitimacy chain" is, as Robert Keohane and Joseph Nye have suggested, to provide for effective politicians who link international organizations to constituencies. ${ }^{18}$ Even if the elected parliamentarians alongside the WTO are not accorded an official function at the beginning, their attendance may evolve into a mediating role before too long.

Once a WTO parliamentary body is established, even an informal one, it could begin to hold public hearings on the key issues of the trading system. The parliamentarians could question national trade officials on their actions and inactions, and also invite economic and social actors to present their views about the future direction of the WTO. ${ }^{19}$ In doing so, the parliamentarians could foster a cosmopolitan debate along the perimeters of the WTO in order to remedy the government-centric debate within the WTO.

Just as parliamentarians carry out a "checks and balances" function at the national level, they can do the same at the international level. The advent of the new trade round in 2002 makes it even more important to establish ongoing parliamentary review of the new negotiations. While it is true that national parliaments can carry out this review at home, such reviews are likely to have an economic nationalist focus and to give short shrift to quasi-public goods at the WTO. For example, it would be unusual for a national parliamentary committee to hold a hearing on whether the WTO has enough staff, or enough funds to carry out technical assistance. Yet those are exactly the kinds of issues that a transnational parliamentary committee would want to examine. As Louise Doswald-Beck has observed, "When members of Parliament are able to consider, in relation to any issue, what solution is in the best interests of the international community and of their own States in the medium-to-long term, they are able to contribute more effectively to global policy-making." 20

Interaction between parliamentarians and nongovernmental organizations would lift the WTO out of its current quandary in which a few developing countries can block efforts to implement fully the WTO organic law authorizing its General Council to "make appropriate arrangements for consultation and cooperation with non-governmental 
organizations concerned with matters relating to those of the WTO." ${ }^{21}$ In other words, the parliamentarians could act as a relay between the executive officials that run the WTO and the private individuals and groups that are affected by the WTO's decisions. Many such individuals live outside of those countries that are Members of the WTO.

Initiating trans-parliamentary oversight of the WTO may also help shore up parliamentary efforts at the national level to review national trade policymaking. The participating politicians will gain both substantive knowledge of world trade law and familiarity with WTO officials and the international NGOs that follow trade closely. This may help national parliaments see the trading system through a wider angle lens.

\section{Some Wider Implications}

The WTO is not alone in lacking a parliamentary dimension. No functional international organizations have one at this time. Although the original idea of the functional organization de-emphasized politics in favor of a technocratic model, no one today would seriously contend that global economic institutions, such as the WTO, the International Labour Organization, or the World Bank, operate outside of politics. The idea of functional specialization is compatible with a process for regular parliamentary input.

A parliamentary advisory body would help reduce the distance between international organizations and democratic decisionmaking at the national level. At the very least, the periodic convocation of parliamentarians at inter-governmental conferences would reinforce the point that such meetings are an extension of national government. Over time, such a convocation might aspire to do even more by deepening the links between the international organization and popular sovereignty. Democracy need not stop at the border.

Looking ahead, one can see possible stepping-stones toward international functional parliaments. One is the establishment of a parliamentary NGO like GLOBE. Another step is an informal meeting like the one that occurred in Doha, organized by a parliament or the IPU. As such meetings become more regular, the national parliaments could be asked to formalize the selection of the delegation to attend the global meeting.

While trans-parliamentary oversight of international organizations is not a panacea to the problems of global governance, this development is certainly a positive step. It is hard to imagine any harm that could come from more oversight by elected officials. If parliamentarians take these efforts seriously and provide space for regular input from social and economic actors, these new initiatives could improve the effectiveness of international organizations. 
Steve Charnovitz is an attorney at the law firm Wilmer, Cutler \& Pickering, in Washington, D.C. He writes frequently on the role of nongovernmental organizations in global governance.

${ }^{1}$ The IPU was established in 1889. See "What is the IPU?", at http://www.ipu.org/english/whatipu.htm.

${ }^{2}$ Parliamentarians for Global Action PGA) was established in 1979. See http://www.pgaction.org/About/Index.htm.

GLOBE was established in 1989. See

http://www.globeinternational.org/background.html.

${ }^{3}$ NATO Parliamentary Assembly, at http://www.naa.be.

4“'Specialized Meetings”, at http://www.ipu.org/strct-e/splzconf.htm.

5"WTO Member Legislators Agree to Form Parliamentary Discussion Forum", Inside U.S. Trade, 3 December 1999.

${ }^{6}$ Mike Moore, "Speech Notes to Legislators Assembly", 2 December 1999, at http://www.wto.org/english/news_e/spmm_e/spmm18_e.htm.

7"Moore calls for closer parliamentary involvement in WTO matters", WTO Press/169, 21 February 2000.

${ }^{8}$ Resolution No. 2/2000 on International Trade Law, Annex 3, available at http://www.ila-hq.org.

9"'WTO Director General Dialogues with MPs at IPU Meeting on International Trade", IPU Press Release No. 119, 9 June 2001, at http://www.ipu.org/press-e/gen119.htm.

${ }^{10}$ Mike Moore, "Promoting openness, fairness and predictability in international trade for the benefit of humanity", Speech to the Inter-Parliamentary Union meeting on international trade, 8 June 2001, available at http://www.wto.org/english/new_e/spmm64_e.htm.

${ }^{11}$ Final Declaration, available at http://www.ipu.org/splz-e/trade01dclr.htm.

12،Parliamentarians for More Transparency and Accountability of World Trade Negotiations", IPU Press Release No. 124, 12 November 2001, at http://www.ipu.org/press-e/gen124.htm. 
${ }^{13}$ Final Declaration/Conclusions, available at http://www.ipu.org/splz-e/doha.htm.

${ }^{14}$ Fergus Watt, "Parliamentarians Have a Role to Play in Doha", Bridges, October 2001, p. 14, available at http://www.ictsd.org.

${ }^{15}$ Ibid.

${ }^{16}$ Ibid.

${ }^{17}$ Pascal Lamy, “Global Policy without Democracy?”, Berlin, 26 November 2001, at http:europa.eu.int/comm/trade/speeches_articles/spla85.en.htm.

${ }^{18}$ Robert O. Keohane \& Joseph S. Nye, Jr., "The Club Model of Multilateral Cooperation and Problems of Democratic Legitimacy", in Efficiency, Equity, and Legitimacy: The Multilateral Trading System at the Millennium (Roger B. Porter, Pierre Sauvé, Arvind Subramanian \& Americo Beviglia-Zampetti eds., Harvard University Center for Business and Government and Brookings Institution Press, 2001), pp. 264-65. For a discussion of the legitimacy chain, see Markus Krajewski, "Democratic Legitimacy and Constitutional Perspectives of WTO Law”, Journal World Trade, Vol. 35, 2001, pp. 167, 181.

${ }^{19}$ Steve Charnovitz, "Economic and Social Actors in the World Trade Organization", ILSA Journal of International and Comparative Law, Vol. 7, No. 2, Spring 2001, p. 259.

${ }^{20}$ Louise Doswald-Beck, "The influence of national parliaments on global policymaking", Berlin, 26 November 2001. Doswald-Beck is the Secretary-General of the International Commission of Jurists.

${ }^{21}$ Marrakesh Agreement Establishing the WTO, Article V:2. 